\title{
Language input, learning environment, and motivation of a successful
} EFL learner

\author{
Arif Nugroho ${ }^{1}$, M. Rizal Akbar Zamzami ${ }^{2}$, Nur Farah Ukhrowiyah ${ }^{3}$ \\ ${ }^{1}$ Department of English Education, Faculty of Adab and Language, State Islamic Institute of \\ Surakarta, Sukoharjo, Jawa Tengah, Indonesia \\ ${ }^{2}$ Department of English Education, Faculty of Teacher Training and Education, Raden Rahmat \\ Islamic University, Malang, Jawa Timur, Indonesia \\ ${ }^{3}$ Department of English Education, Faculty of Culture and Humanities, State Islamic \\ University of Maulana Malik Ibrahim, Malang, Jawa Timur, Indonesia \\ ${ }^{1}$ arif.nugroho@iain-surakarta.ac.id (corresponding author) \\ 2 m.rizalzamzami@uniramalang.ac.id \\ ${ }^{3}$ n.farahukhrowiyah@uin-malang.ac.id
}

\begin{abstract}
The present study involved one EFL learner who was regarded as successful, not only of understanding second language acquisition theories but also of demonstrating exceptional language skills thus far. An in-depth semistructured interview was administered with three key objectives - to identify features of language inputs that enable her to develop English skills, to investigate her situation of the learning environment, and to reveal her motivation in learning the language. The participant was a successful EFL learner who was determined by the excellent TOEFL score and performed an outstanding achievement in English proven by the academic transcript. The data were gathered by means of a semi-structured interview and analyzed through the transcription process, coding, and drawing the conclusion. The results indicated that joining an intensive class and integrating English in her daily activities had primarily contributed to her language skill improvement. While the physical environment slightly provided a conducive environment for learning English, her academic environment was steadily supporting her. In addition to the importance of English in her future, the participant was successful in keeping her motivation to learn the language. These findings
\end{abstract}

Journal on English as a Foreign Language, 10(1), 45-67

Copyright @ 2020 by JEFL, p-ISSN 2088-1657; e-ISSN 2502-6615 
could contribute to a better understanding of how Indonesian EFL learners successfully acquire a foreign language.

Keywords: language input; learning environment; motivation; EFL learner

How to cite this paper (in APA style): Nugroho, A., Zamzami, M. R. A., \& Ukhrowiyah, N. F. (2020). Language input, learning environment, and motivation of a successful EFL learner. Journal on English as a Foreign Language, 10(1), 45-67. https://doi.org/10.23971 ßefl.v10i1.1511

DOI: https: //doi.org/10.23971/jefl.v10i1.1511

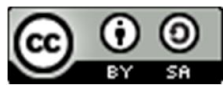

Scholars have conducted studies on the importance of promoting English as a second or foreign language. Learners' acquisition of a second language much depends on their exposure and experience of the language and to what extent they make use of it (Ellis \& Collins, 2009). For recent years, accounts of a successful language acquisition have accordingly emphasized on the quality of language inputs (Bahrani \& Soltani, 2012; Maharsi, 2016; Nguyen \& Franken, 2010), learning environment (Kiatkheeree, 2018; Vidaček-Hainš et al., 2010), and motivation (Dörnyei \& Schmidt, 2001; Masgoret \& Gardner, 2003).

In a language acquisition process, it is undeniable that input is considered as very important. It plays a role as 'an obligatory entry point' that considerably contributes to the success of language acquisition. A study on language input conducted by Maharsi (2016) pointed out that the right size and form of input seemly result in more successful language acquisition. In a similar direction, Bahrani and Soltani (2012) investigated the role of language input in second language acquisition and concluded that second language acquisition was carried out by considering having optimal exposure to the target language. O'Grady et al. (2011) also emphasized the role of input in SLA by notifying that some language features, in a language acquisition case, are directly shaped by the input. In other words, therefore, the process of language acquisition is highly influenced by the appropriate and availability of language input (Bahrani \& Nekoueizadeh, 2014).

Most EFL learners, especially in Indonesia, are depending mainly upon regular classroom learning to enhance their English ability (Budiharto \& Amalia, 2019). The only place most EFL learners are exposed to the foreign language is in the classroom (Wang, 2010). A primary theory of input, which is

Journal on English as a Foreign Language, 10(1), 45-67

Copyright @ 2020 by JEFL, p-ISSN 2088-1657; e-ISSN 2502-6615 
known as the Input Hypothesis, is proposed by Krashen (2002). The developed form of input is that "exposure to comprehensible input is both necessary and sufficient for second language learning to take place" (Krashen, 2002, p. 165). According to Krashen (2002), EFL learners must be provided with a lesson that is "a little beyond their current level of competence." Learners are required to process the input into comprehension, and one of the ways to comprehend the input is through simplification (Krashen, 2002, p. 165). Thus, the essential point is that input has to be processed to become intake. As highlighted by Gass et al. (2013), intake is the input that is "internalized" (Gass et al., 2013, p. 260). It indicated that input should be given sufficient attention to make second language learning progress. In particular, the input should be comprehensible and should become intake to proceed to second language acquisition (Maharsi, 2016).

Krashen (2002) adds that the only causative variable in language acquisition is comprehensible input. Following this, Ellis (2008) has supported the input hypothesis by suggesting three potential types of comprehensible input, namely unmodified input, pre-modified input, and interactionally modified input. According to her, unmodified input or baseline input refers to a language input that is not modified for comprehension. Moreover, she defines pre-modified input as an input that is modified or simplified before it is delivered to the EFL learners to boost the comprehension process. Furthermore, the interactionally modified input is modified through meaning negotiation to make the input more comprehensible.

Another essential factor contributing to the development of learners' language acquisition is the learning environment. Studies in second language acquisition indicate that a conducive learning environment has significantly affected the proficiency of EFL learners. Teachers' and students' interaction in a classroom, for instance, as part of a learning environment, is considered as an essential factor in promoting learners' language achievement (Opdenakker \& Van Damme, 2006). According to Appatova and Prats (2007), a productive learning environment constitutes an open system of variable factors influencing student learning effectiveness, as seen from the perspective of learners, administrators, faculty members, and professional staff. How the students see their learning environments will potentially impact the way the students cope with these learning environments (Gijbels et al., 2006). Thus, a conducive learning environment facilitates the success of EFL learners in acquiring the language.

Journal on English as a Foreign Language, 10(1), 45-67

Copyright @ 2020 by JEFL, p-ISSN 2088-1657; e-ISSN 2502-6615 
Kiatkheeree (2018) divides the learning environment into three: academic environment, physical environment, and psychological environment. Regarding the academic environment, teachers play an essential role as a crucial factor in promoting a positive learning environment that includes having good knowledge of the subject matter, understanding of the curriculum and its purpose, and reflecting on their teaching (Kiatkheeree, 2018, p.391). This statement is following Lizzio et al. (2002), in which a positive academic environment constitutes good teaching, clear goals, and appropriate assessment. As an academic environment affects learners' achievement, the physical environment is also considered as an essential factor in supporting EFL learners. The physical environment consists of all related things that human acts, such as noise, crowding, housing, and quality of the neighborhood (Punthumasen, 2007). Also, Koko (2007) asserts that learners' abilities and their cognitive development are influenced by the psychological environment, which encompasses motivation and awareness. It is undeniable that these learning environments affect students' success in language acquisition. Therefore, students, teachers, and all people who participated in the educational system have to be studied to gain insights into promoting a productive learning environment.

Moreover, the most frequently studied variable in language acquisition, which also significantly contributes to the learners' proficiency, is motivation. For recent years, motivation has been considered as a central area for empirical research and the development of theoretical work in the language learning context (Rajab et al., 2012). Several studies in this area show that motivation has an essential role in language learning since it surely encourages EFL learners to maintain effort (Dörnyei \& Chan, 2013). It increases learners' language proficiency (Gardner, 2001) and establishes the autonomy of EFL learners (Spratt et al., 2002). Samad et al. (2012) found out the correlation between motivation and Iranian EFL learners' language proficiency and revealed that the high achievers' language proficiency positively correlated with motivation. In a similar study, Alizadeh (2016) concluded that motivation played a crucial role and had a significant contribution to successful EFL learners.

Further, Mulalić and Obralic (2016) examined the relationship between motivational components and learning method preference among IUS students. The finding showed that extrinsic motivation was the most influential factor for the students. In addition, a study carried out by Fadilah (2018) found that motivation affected directly to the students' willingness to communicate in

Journal on English as a Foreign Language, 10(1), 45-67

Copyright @ 2020 by JEFL, p-ISSN 2088-1657; e-ISSN 2502-6615 
English. Thus, these results of studies indicated that learners' language acquisition has positively correlated with the degree of motivation they had.

Discussing motivation in language acquisition, Self-Determination Theory (hereafter SDT) is one of the primary theories in this field. SDT introduces the notion of behavior regulation to account for one's motivational orientations to perform a particular behavior (Deci \& Ryan, 2000). When action is performed because of a sense of enjoyment, pleasure, or satisfaction, the person is said to be intrinsically motivated, which is performing such behavior from oneself (Lucas et al., 2010). Intrinsic motivation is highly self-determined and is the most autonomous type of behavior (Black \& Deci, 2000). In contrast, if a person acts to get a reward or to avoid punishment, he/she is considered to be extrinsically motivated. In this case, the performance of doing an action is controlled by external factors beyond himself. A person who is extrinsically motivated is either do not enact their behaviors volitionally or perform their behaviors with a limited sense of volition (Deci \& Ryan, 2000; Lucas et al., 2010). Therefore, extrinsically motivated performance is subsequently a lack of selfdetermination.

The most recent theoretical literature of motivation in second language acquisition studies is introduced by Dörnyei and Chan (2013), which refers to the L2 Motivational self-system. Since its conception, this theory of motivation has dominated researches incorporating motivation in the field of language acquisition. In his new theory of motivation, Dornyei points out three different, but the inter-related concept of motivation referred to ideal L2 self, ought to L2 self and L2 learning experience.

At first, the term ideal L2 self refers to "the representation of the attributes that one would ideally like to possess" (Dörnyei \& Ushioda, 2009, p. 224). In the Indonesian EFL context, ideal L2 self may be interpreted as being a proficient speaker of English, in which case the skills could enable the learners to interact with the international community or to get a better job in the globalized world (Albert, 2018). Second, the ought to L2 self refers to "the envisioned quality that an EFL learner should possess, either owing to their responsibilities or avoid undesirable consequences" (Dörnyei \& Chan, 2013; Dörnyei \& Schmidt, 2001, p. 94; Dörnyei \& Ushioda, 2009). The concept of ought to L2 self is influenced by the existence of external pressures. Hence, from the standpoint of SDT, it is considered to integrate with the external factors or well-known as extrinsic motivation. Finally, the L2 learning experience refers to "situation-specific motives related to the immediate

Journal on English as a Foreign Language, 10(1), 45-67

Copyright (C) 2020 by JEFL, p-ISSN 2088-1657; e-ISSN 2502-6615 
learning environment and experiences" (Dörnyei \& Ushioda, 2009, p. 69). It is unlike the two concepts in which L2 learning experience is closely related to factors such as classroom environment, peers, teacher, curriculum, teaching method, and learning facilities. For example, a particular learning environment may be more interesting than others; thus, it affects EFL learners' motivation to learn a language.

Most scholars and researchers in the area of second language acquisition justify that the three variables above have a significant contribution in developing EFL learners' language acquisition. A study conducted by Harrington and Dennis (2002), taking into account language input, concluded that the task frequency played an essential role in the input-driven approach and language learning process. It indicates that pre-modified input by utilizing frequency task significantly facilitates the EFL learners' comprehension. Further, about the learning environment, a study by Kiatkheeree (2018) revealed that the physical environment, academic environment, and psychological environment had affected the students' language acquisition. In the Indonesian EFL context, moreover, Albert (2018) explored students' motivational orientations for learning English as a foreign language at the high school level. The results indicated that "ideal L2 self" was the most-dominant orientation perceived by those students. Also, the finding of Budiharto and Amalia's (2019) study emphasized that motivation was the key incentive of learners' performance, which was strongly influenced by intrinsic and extrinsic motivational orientations.

As far as we concerned about these previous findings, however, Harrington and Dennis's (2002) study only limited its scope on the premodified input through task frequency experienced by the participants. It slightly provides an overall input description, as seen from the experiences of successful EFL learners. Moreover, although Kiatkheeree's (2018) research provided a comprehensive understanding of how physical, academic, and psychological factors affected students' achievement, it did not specifically investigate a language learning environment experienced by a successful EFL learner, which could be used as practical literature by other EFL learners. As a further matter, research findings showed by Alberth (2018) and Budiharto and Amalia (2019) in the Indonesian EFL context have already provided a comprehension of Self-Determination Theory (Deci \& Ryan, 2000) and L2 Motivational self-system (Dörnyei \& Chan, 2013). Notwithstanding the fact, examining motivational orientations of a successful EFL learner will undoubtedly enrich the literature of maintaining motivation in language

Journal on English as a Foreign Language, 10(1), 45-67

Copyright @ 2020 by JEFL, p-ISSN 2088-1657; e-ISSN 2502-6615 
acquisition for EFL learners. The present study, therefore, investigates language input, learning environment, and motivational orientations as experienced by a successful EFL learner.

Besides, research incorporating the three variables in second language acquisition is still scant until to date, especially in the case of a successful Indonesian EFL learner. The present study, as a result, seeks to fill the gap and provide a practical contribution to the literature of what components and sources of promoting students' success in learning English through examining the language input, learning environment, and motivation of a successful EFL learner. Thus, the results of this study can be an alternative model for other EFL learners who are willing to enhance their English skills. Also, this study provides a clear understanding of how EFL teachers should encourage their students to be successful EFL learners. Accordingly, by employing a semistructured interview, this study is guided under the following key aims: (1) to identify the features of language input experienced by a successful EFL learner; (2) to investigate the learning environment experienced by a successful EFL learner; and (3) to reveal how a successful EFL learner maintain her motivation in learning a foreign language.

\section{METHOD}

\section{Research Design}

This study is a case study involving one EFL learner of a non-English department in Indonesia. Time and resource limitations prevented us from reaching the ideal number of participants (6-10), as suggested by Dörnyei (2007). However, this study still presents a rich delineation of the availability of language inputs, learning environment, and motivation experienced by the participant. Also, we provided a clear boundary and criteria to determine which participants could be involved in this study. This is important as an effort to recompense for the small number of the participant in this study.

\section{The Participant}

The participant of this study was a successful EFL learner who was determined based on the following criteria. Foremost, to be considered as a successful EFL learner, the participant must acquire a good understanding of English knowledge and perform excellent language skills, which were proven by the TOEFL score. Second, the participant should perform an exceptional academic achievement in the subject of English that was manifested on the

Journal on English as a Foreign Language, 10(1), 45-67

Copyright @ 2020 by JEFL, p-ISSN 2088-1657; e-ISSN 2502-6615 
academic transcript. Also, the participant had to be considered as an active student in classroom activities. Although this study only involved a participant, it still offers a rich description. A case study involving one participant still provides an in-depth understanding of the data were comprehensively analyzed (Yin, 2015).

Novia (pseudonym) is an eligible EFL learner who matches the criteria. She started studying at the department of Islamic Primary School Teacher Education in 2015 of a public Islamic university. She comes from a relatively disadvantaged area, as typified by the fact that her region belonged to one of the remote regions of the province. Interestingly, despite coming from such an area, Novia has been successful in maintaining her positive commitment and strong motivation by continuously performing an outstanding effort to continue her studies.

\section{Instrument}

The data were gathered through a semi-structured interview. The benefit of this instrument is that the interviewer possesses structured guidance in hand. However, it is still possible to diverge from the guidance when a new issue arises during the dialogue (Dörnyei, 2007). The semi-structured interview is applicable in this study since it is relevant to reach an in-depth understanding when the researcher has been familiar with the phenomenon and context (Dörnyei, 2007).

To achieve the objectives of this study, the interview guide comprised four main sections. The first section contained personal information of the participant, while the second part examined the availability of her English inputs. The third section concerned with the description of the learning environment experienced by the participant. Moreover, in the last section, the participant was required to share experience on how she kept her motivation in learning the foreign language. In anticipating additional information that the participant wanted to convey, we allowed her to deliver her final remarks before ending the conversation.

\section{Data Collection}

During the data collection, the interview was recorded attentively. It was conducted in English as an attempt to prove that she was a successful EFL learner. Before the interview began, the participant was already informed that any data she gave through the interview would be kept securely and deleted as 
soon as the research finished. She was also kindly requested that her real name would not be used in this article to ensure her privacy.

The interview was begun with asking the personal information of the participant such as her identity and family background. The participant was asked to explain from which she gained the language inputs that made her perform excellent English. After that, the interviewer asked about the situation of her learning environment including the physical environment, academic environment, and psychological environment. In the last section, the participants were required to reveal how she continuously kept her motivation in learning and practicing English. The interview was conducted until a saturation point was achieved. The saturation point is the point when there is no new information during the process of the interview.

\section{Data Analysis}

The data were then analyzed by conducting some procedures. First, since the primary data were in the form of audio recording, it was initially transliterated into written data through a transcription process. Second, the data were coded by referring to the coding process, as recommended by Creswell (2005). The first stage of the coding process was reading the transcription consisting of several pages to simplify into smaller segments to highlight new information that was related to the topic of this study. Afterward, we provided codes to the underlined utterances, which considerably matched to the topic discussion. Following this, we identify redundant codes and categorized them into fewer codes. Finally, we reduced the codes again to create themes that were appropriate to the objectives of this study.

\section{FINDINGS}

This section delineates the findings of the three research questions concerning the language input experienced by a successful EFL learner, the learning environment, and her motivation in learning the foreign language. It also discusses the finding concerning relevant literature. Several statements of the participant are quoted verbatim to support the delineation of the findings.

\section{The Language Inputs of a Successful EFL Learner}

The first section of the finding concerns the language input experienced by Novia. Based on the result of the data analysis, both classroom input and 
beyond classroom input clearly contributed to her language development. The detail description is presented in Table 1.

Table 1. The language inputs of a successful EFL learner

\begin{tabular}{|c|c|c|}
\hline No & Types of inputs & Description \\
\hline 1 & Classroom input & $\begin{array}{l}\text { - Intensive English class on IELTS and } \\
\text { speaking skills. } \\
\text { - English for specific purposes course as } \\
\text { the compulsory subject. }\end{array}$ \\
\hline 2 & Beyond classroom input & $\begin{array}{l}\text { - Watching English movies, listening to } \\
\text { music, and reading English novels. } \\
\text { - Being an active member of English } \\
\text { communities. }\end{array}$ \\
\hline
\end{tabular}

According to Table 1, joining the intensive English on IELTS and the English for specific purposes classes were the two major sources of Novia's classroom inputs. At the beginning of her fifth semester in the undergraduate program, she decided to enroll in an intensive English class. The intensive course paid more attention to IELTS training and speaking skill enhancement. This program was offered by the university to facilitate students who wanted to improve their English skills, especially with gaining a high score of IELTS and performing better speaking ability. In the intensive class, she was one of the only few other members of the class who came from the non-English department. At the same time, she also took an English 2 course in her regular class as a compulsory subject in that semester. The course was divided into two classes - one was concerning in reading skill, and the other was developing the skill of writing. According to her, the two classes (regular and intensive) were exciting and enjoyable. The instructors of the intensive class were able to explain the materials so that the learners, including Novia, quickly understood them, unlike what people often said that such English materials were slightly natural to be understood, especially by non-English department students.

Novia commented that the decision to join the intensive class, which was beyond her regular schedule, really affected her English proficiency. So, she thought that she performed an excellent choice:

This semester, I have an English 2 course as my compulsory subject, which is focusing on reading and writing. However, I want to look for other sources to improve my English skill, and I decide to join an intensive English class because the campus 
conducts it this semester. It focuses on IELTS training and speaking.

She also added that:

Mmmmm... I don't really know why I quickly understand the materials given by the teacher, maybe because the teacher is good at delivering those materials, especially in intensive class.

In addition, Novia told that she obtained the input for learning English not only from academic teaching in the classroom but also from outside the classroom. The interview revealed that she regularly watched English movies, listened to music, and read novels. Among the three activities, reading a novel was her most favorite. She added that the "Chicken Soup" series was her best-loved novel, especially in the title of "The Old Man and a Child." She read this novel four to five times a week and thought that it was very inspiring and made her learn about the moral values of the story. The most interesting point was that when she encountered strange words while reading the novel, she immediately found the meaning by looking up the dictionary or searching them at Google:

I very love to, you know, watch English movies so I learn the language from there and you know chicken soup novel? I love it, very love it. I like reading "The old man and a child," and if I have difficult words, I search on my dictionary or Google.

Another interesting part of the interview with Novia was that, when she was asked about her other input activity to promote English proficiency, she actively involved herself in an English community at her campus. It was such an English debate community where Novia frequently practice her speaking English even every day. She consciously recognized that her involvement in the English community significantly contributed to her English proficiency:

Hmmm... I join an English debate community on campus, or you know, like UKM [students' community], and I am sure it really helps me to have a regular practice of my English, especially my speaking.

In a nutshell, the result of this study concerning the language input of a successful EFL learner revealed that both classroom input and beyond classroom input contribute to the development of Novia's language skills. Joining an English intensive class and an English for specific purposes course 
have successfully enhanced her English ability. Moreover, what she has done in an outside classroom, i.e. watching English movies, listening to music, reading English novels, and actively joining an English community, continuously improves her English proficiency.

\section{The Learning Environment of a Successful EFL learner}

The second section of the finding concerns the learning environment experienced by Novia. The result of the data analysis shows that the academic environment and physical environment highly contributed to the enhancement of her language skills. The detail description of this finding is illustrated in Table 2.

Table 2. The learning environment of a successful EFL learner

\begin{tabular}{|c|c|c|}
\hline No & Types of environment & Description \\
\hline 1 & Academic environment & $\begin{array}{l}\text { - Conducive learning situation of the } \\
\text { intensive and regular classes. } \\
\text { - Kindly support from the academic staff } \\
\text { of the faculty. }\end{array}$ \\
\hline 2 & Physical environment & $\begin{array}{l}\text { - Regular practices with fellow friends in } \\
\text { the boarding house. }\end{array}$ \\
\hline
\end{tabular}

As depicted in Table 2, the semi-structured interview with Novia concerning her learning environment revealed that the academic environment, i.e., the situation of regular and intensive English classes and her perception toward the academic staff, seemed to be the most influenced factor of her excellent English proficiency. When she was asked about her opinion of the environment in her classes, she said that the classes where she was involved in provided a conducive learning environment. She also stated that these classroom environments made her encouraged always to perform the best achievement. Besides, she also pointed out that the academic staff in her faculty helped support her educational activities while at the campus, for instance, in preparing all learning facilities:

Yes, the situation of my classes is delightful and can support me to learn and practice English. The class is very, very conducive, my friend is, ehhmm...., are very nice and yaaa... it is joyful."

She also added that: 
.... and fortunately I am chosen as the captain in my class, so I often ask for help from the academic staff, and they are really helpful and nice people.

Moreover, when she was being asked to give her opinion about the learning situation in her family, she said that her family did not give her insights for learning English. It may potentially due to her family lived in a disadvantaged area where performing English became a strange behavior. It could be stated that her family did not use English at all. When she was asked whether she tried to speak English with her family, she only answered that maybe when her parents asked to do something, she said "yes sir" or "yes mom" to them. In contrast, Novia uttered that her fellow friends at the boarding house and the campus were supported her in learning English. It was reflected by she was often practicing English, especially speaking with her friends. Additionally, her friends frequently asked her to help in doing an assignment or project related to English:

hmmm and maybe when my parents ask me to do something I try to say "yes mom" or "yes sir," like that. Maybe only a simple dialogue.

She also stated that:

Yes, I often practice with my friends. They are also, hmmm....., asking me to help if they found difficult words and, a - a, often help them to do their tasks and English project.

In conclusion, Novia experiences several situations in a learning environment. Her academic learning environment seems to be the most influential factor affecting her outstanding language proficiency. Her positive perception toward the academic staff becomes an interesting finding of this study. Furthermore, performing regular practices with her fellow friends in the boarding house continuously provides a positive environment of language learning in enhancing her English ability.

\section{The Motivation of a Successful EFL Learner}

The third section of the finding deals with the Novia's motivation in learning a foreign language. The result shows that the desire to obtain the best remark in her English classes and the commitment to get an excellent job in the future highly motivate her in learning the foreign language. The findings reveal

Journal on English as a Foreign Language, 10(1), 45-67

Copyright @ 2020 by JEFL, p-ISSN 2088-1657; e-ISSN 2502-6615 
that Novia is intrinsically and extrinsically motivated. The detail description of this finding is depicted in Table 3.

Table 3. The motivation of a successful EFL learner

\begin{tabular}{cll}
\hline No & Types of motivation & \multicolumn{1}{c}{ Description } \\
\hline 1 & Intrinsic motivation & $\begin{array}{l}\text { The commitment to getting a promising } \\
\text { job in the future }\end{array}$ \\
2 & Extrinsic motivation & $\begin{array}{l}\text { The desire to impress the teachers and } \\
\text { obtain the best remark in English classes }\end{array}$ \\
& &
\end{tabular}

Novia's desire to get the best remark on every class she was involved in made her motivated to give an outstanding performance both in her regular English class and in the intensive class. It is reflected by her discipline and excellent efforts to always accomplish what her teachers want to do, such as practicing conversation, doing assignments, and finishing a project. She commented:

I always, always try to do..., a - a, do my best during the process of teaching and activities in the class. You know..., a - a, I always finish my homework on time and I try to keep discipline. I want to get the best score in every subject, a - a I have I take this semester because I want to make my parents happy with my academic score.

In addition, the interview also revealed her other motivation as an EFL learner. She realized that English was an important language skill that should be acquired to pursue her future. Thus, she was craving for being an English professional practitioner, although she came from a non-English department. Her only dream was that she could play an essential role as part of communication with people around the world and get an excellent job for her future in this globalization era. She stated:

..... and in my opinion, English is very very important for my better future. If other people can, $a-a$, can master it, I believe that I also can do it. I want to be a professional person in English although I am not an English department student. My dream someday is, $\mathrm{a}-\mathrm{a}$, I want to be able to compete, $\mathrm{a}-\mathrm{a}$, to compete in this globalization era and to get a good job in my future.

To sum up, Novia's outstanding performance in English is highly motivated by intrinsic and extrinsic factors. The commitments to get a good job 
in the future and to be able to actively take a role in the globalization era make her motivated in learning English. Also, the desire to always obtain a good remark in her English classes motivates her to continuously enhance her language skills.

The findings of the present study indicate that the participant experiences several types of language inputs, learning environment, and motivation in order to get the predicate of a successful EFL learner. She obtains language inputs from inside the classroom and beyond the classroom, such as English classes, movies, novels, and English communities. The academic and physical environment, where the participant is involved in, steadily support her language development. Moreover, the participant of this study is a highlymotivated EFL learner who always performs her best in every English classroom and commits to getting a promising job in the future.

\section{DISCUSSION}

\section{Features of Language Input}

Based on the above finding, it is clearly revealed that the language inputs experienced by Novia are, in general, categorized into classroom input and beyond classroom input. The classroom input means language input that is obtained from academic and teaching activities in the classroom. This encompasses regular and intensive classes enrolled by Novia that affect her English proficiency level. It indicates that her instructors seem to have an essential role in giving insights for Novia to develop her language skills. This is clearly in line with what has been stated by Wang (2010) that the most exposed place for EFL learners to learn a second/foreign language is the classroom through teaching activities provided by the instructors.

Furthermore, concerning the input hypothesis proposed by Krashen (2002), the finding of this study supports his hypothesis in which EFL learners should be provided an insight which is a little beyond their current levels of competence. It is reflected by the decision of Novia to enroll in the intensive English class where the higher level of English materials is provided there. She sees her regular English class as necessary, however, she also recognizes that she needs other English materials, which are "a little beyond her level of competence" and challenging as an insight for the improvement of her language proficiency. As a result, she performed the best decision.

Journal on English as a Foreign Language, 10(1), 45-67

Copyright @ 2020 by JEFL, p-ISSN 2088-1657; e-ISSN 2502-6615 
The beyond classroom input, as reflected by the normal behavior of watching English movies, listening to the song, and reading English novels, cannot seemly be put aside. Integrating English in daily life by performing such behaviors undeniably contribute to the enhancement of EFL learners' ability. These input activities, according to the classification of input by Ellis and Collins (2009), are considered as unmodified input or baseline input since they are not modified for comprehension. The English movie, song, and novel are natural sources of language inputs that the learners must try to proceed to become intake by understanding the language without having the ability to modify them. Also, the participant had experienced the interactionally modified input when she was joining the English debate community. Through the regular practice of speaking English, she frequently modified the obtained input and tried to negotiate the meaning when delivering statements to make the input comprehensible for her interlocutors.

In terms of language input, the finding of this current study is consistent with the result of a study conducted by Harrington and Dennis (2002). The result of their investigation of input-driven in second language learning indicated that task frequency played an essential role in the acquisition of the second language (Wang, 2010). The finding implicates that pre-modified input as highlighted by Kiatkheeree (2018) through task frequency has an essential part in facilitating EFL learners' comprehension. In this study, the participant's explanation of the easiness in understanding English materials in her classes while other students commonly perceive them as difficult may indicate that her instructors have modified the materials before delivering them to the students. Therefore, in some cases, pre-modified input to make it more understandable is considerable to be taken into account in the context of EFL teaching.

To conclude this section, it was indicated that Novia experienced several constructs of language input that firmly affect her outstanding English proficiency. She consistently maximized the availability of language input around her, including actively performing excellent achievement in her regular and intensive English classes and adding normal behaviors such as watching English movies, listening to songs, and reading novels on her daily basis outside the classroom. To enhance her speaking skills, she also continuously practiced by joining an English community. 


\section{The Situation of Learning Environment}

It was revealed that the academic environment experienced by the participant had been considered as the most influenced learning environment contributing to her English acquisition. Interestingly, this finding is not consistent with what has been concluded by Kiatkheeree (2018) in which the physical environment was regarded as the most crucial factor in promoting students' language achievement. However, we think that these two findings agreed in terms of providing a conducive learning environment for EFL learners, which include the academic and physical environment in it. This appears to affirm the statement of Appatova and Prats (2007) in which they stated that a productive learning environment constitutes an open system of variable factors that influence the effectiveness of student learning, as seen from the perspective of learners, administrators, faculty members, and professional staff.

Analyzing Croatian and American students' needs for support services to improve the learning environment effectiveness at a higher education institution, Vidaček-Hainš et al. (2010) found that the students suggested enhancing the quality of learning environment by improving the support service as well as the academic staff. The result had not agreed with what had been found in the present study. The information given by Novia regarding the academic staff in her campus indicated that the support services of learning activities such as administrative data, classroom facilities, and other supported devices were sufficient to assist an active learning environment as concluded by Kiatkheeree (2018). Since both studies were conducted in the different contexts of the learning environment, it was not surprising when the finding resulted in a different outcome as long as still in the same field of study. The two findings, then, are used as a meaningful insight to conduct future researches in a second language acquisition context.

To sum up, the data of the interview showed that the participant experienced an active classroom and her neighborhood environment while her family was not. However, since she was seen as a highly motivated learner, she was able to cope with the situation of her learning environment. Her behavior to always think positively also made her survive in acquiring English.

Journal on English as a Foreign Language, 10(1), 45-67

Copyright @ 2020 by JEFL, p-ISSN 2088-1657; e-ISSN 2502-6615 


\section{The Motivation of Learning a Foreign Language}

Novia's motivation in learning English cannot be taken for granted in terms of what she has achieved in her language proficiency. The result of data analysis indicates that Novia is a highly-motivated EFL learner. What Keller (2010) says about the motivation that refers broadly to what people desire, what they want to achieve, and what they commit to doing is seemly proven by the finding of this study.

From the standpoint of SDT, Novia's desire to get the best remark on every subject reflects extrinsic orientation, simply because the motive for learning English emanates from outside the person. In this case, it was triggered by a reward in the form of a suitable remark of the English course she took. This is in agreement with what has been stated by Black and Deci (2000) that a person who acts to get a reward or avoid punishment, she/he is extrinsically motivated. On the other hand, the second component contains items indicating the participant's inclination to acquire English for the sake of her better future. Additionally, she wanted to master English as a means of communication in the globalization era. These typical orientations, according to the concept of SDT, are commonly known as intrinsic motivation in which the performed behavior is because of a sense of satisfaction (Deci \& Ryan, 2000), simply because the motive for learning English emanates from inside of the person (Suciati, 2016).

Interestingly, this finding appears to affirm the results of similar studies in the past conducted by Budiharto and Amalia (2019). According to them, motivation was the key incentive of learners' performance in learning a target language. They also revealed that intrinsic and extrinsic motivation primarily provided a strong influence on the students' language achievement. Thus, both findings of the studies reaffirm the importance of being motivated intrinsically and extrinsically for the success of learning a second foreign language. Also, an interesting statement has been stated by Dörnyei and Chan (2013) when he said that motivation helped EFL learners maintain their efforts. Then, it is proven by Novia, who always puts her motivation at a high level, as reflected by her outstanding efforts to be a successful EFL learner.

As far as L2 Motivational Self System is concerned, Novia's orientations in learning English are still related to ideal L2 Self (i.e., being an envisaged proficient English speaker and getting an excellent job for her better future). This finding supports Alberth's (2018) idea of ideal L2 self in Indonesian EFL context, that is "ideal L2 self may be interpreted as being a proficient speaker of

Journal on English as a Foreign Language, 10(1), 45-67

Copyright @ 2020 by JEFL, p-ISSN 2088-1657; e-ISSN 2502-6615 
English, in which the skills could enable the learners to interact with the international community or to get a better job in the globalized world". It was also consistent with the results of an investigation of undergraduate students' motivational orientations for learning English, which found that ideal L2 self was the most underlined motivational dimension of the students in learning English (Budiharto \& Amalia, 2019).

Last but not least, Novia's motivational orientations for learning English are attributed to the fact that she finds learning English as exciting and fun. As revealed earlier, she decided to learn English simply because she wanted to get the best remark of her courses and dreamed to actively use English as a means of communication in the globalization era, so that she would obtain a remarkable job for her better future. Hence, the findings of the present study suggest an insight into motivational orientations for being a successful EFL learner.

\section{CONCLUSION}

The participant in this study experiences exceptional language inputs and learning environments. Additionally, her motivational orientations significantly affect her outstanding achievement as an EFL learner. The findings of this study provide a practical contribution as an alternative model for other EFL learners who are willing to enhance their English skills. This study also provides a clear understanding of how EFL teachers should encourage their students to be successful EFL learners. It is expected that this article will have many insights for other researches that share similar issues to the case in this study. However, it should be noted that the single case in this present study could not represent Indonesian EFL learners in general. Therefore, the authors suggest a large project should be conducted about language input and learning environment experienced by EFL students as well as their motivational orientations to be a successful EFL learner.

\section{REFERENCES}

Alberth. (2018). Indonesian high school student motivational orientations for learning English as a foreign language: Some preliminary findings. Electronic Journal of Foreign Language Teaching, 15(2), 304-321.

Alizadeh, M. (2016). The impact of motivation on English language learning. International Journal of Research in English Education, 1(1), 11-15.

Appatova, V., \& Prats, H. (2007). Effective academic environment for underprepared college/university learners: Listen to student voices. In 16th 
EAN Annual Conference Access to Success: The Student Experience from PreEntry to Employment. Galway: National University of Ireland.

Bahrani, T., \& Nekoueizadeh, M. (2014). The role of input in second language acquisition. Journal of Advances in Linguistics, 1(1), 1-6. https://doi.org/10.24297 jal.v1i1.1986

Bahrani, T., \& Soltani, R. (2012). Language input and second language acquisition. Journal of Education and Practice, 3(3), 39-43.

Black, A. E., \& Deci, E. L. (2000). The effects of instructors' autonomy support and students' autonomous motivation on learning organic chemistry: A self-determination theory perspective. Science Education, 84(6), 740-756. https://doi.org/10.1002/1098-237X(200011)84:6<740::AID-SCE4>3.0.CO;2-3

Budiharto, R. A., \& Amalia, L. (2019). Motivation behind Indonesian undergraduates learning English as a target language. IDEAS: Journal on English Language Teaching and Learning, Linguistics and Literature, 7(1), 114. https://doi.org/10.24256/ideas.v7i1.714

Creswell, J. (2005). Educational research: Planning, conducting, and evaluating quantitative and qualitative research. Upper Saddle River, NJ: Merrill.

Deci, E. L., \& Ryan, R. M. (2000). The" what" and" why" of goal pursuits: Human needs and the self-determination of behavior. Psychological Inquiry, 11(4), 227-268. https://doi.org/10.1207/\$15327965PLI1104_01

Dörnyei, Z. (2007). Research methods in applied linguistics: Quantitative, qualitative, and mixed methodologies. Oxford: Oxford University Press.

Dörnyei, Z., \& Chan, L. (2013). Motivation and vision: An analysis of future L2 self-images, sensory styles, and imagery capacity across two target languages. Language Learning: A Journal of Research in Language Studies, 63(3), 437-462. https://doi.org/10.1111/Aang.12005

Dörnyei, Z., \& Schmidt, R. W. (2001). Motivation and second language acquisition. Honolulu, HI: Second Language Teaching \& Curriculum Center, University of Hawaii at Mānoa.

Dörnyei, Z., \& Ushioda, E. (Eds.). (2009). Motivation, language identity, and the L2 self. Multilingual Matters. Retrieved from http://www.multilingualmatters.com/display.asp?isb $=9781847691279$

Ellis, N., \& Collins, L. (2009). Input and second language acquisition: The roles of frequency, form, and function introduction to the special issue. The Modern Language Journal, 93(3), 329-335. https://doi.org/10.1111 ß.15404781.2009.00893.x

Ellis, R. (2008). The study of second language acquisition. Oxford: Oxford University Press.

Fadilah, E. (2018). Perception, motivation, and communicative self-confidence 
of Indonesian students on willingness to communicate in L2 by using Facebook. JEELS (Journal of English Education and Linguistics Studies), 5(1), 23-48. https://doi.org/10.30762 heels.v5i1.562

Gardner, R. C. (2001). Integrative motivation and second language acquisition. Motivation and Second Language Acquisition, 23, 1-19.

Gass, S. M., Behney, J., \& Plonsky, L. (2013). Second language acquisition: An introductory course ( $4^{\text {th }}$ ed.). Routledge.

Gijbels, D., Van De Watering, G., Dochy, F., \& Van Den Bossche, P. (2006). New learning environments and constructivism: The students' perspective. Instructional Science, 34, 213-226. https://doi.org/10.1007/s11251-005-3347$\mathrm{Z}$

Harrington, M., \& Dennis, S. (2002). Input-driven language learning. Studies in Second Language Acquisition, 24(2), 261-268. https://doi.org/10.1017/50272263102002103

Koko, K. (2007). The effects of the physical environment on children's development. Ithaca, NY: Cornell Department of Human Development, $\mathrm{Nd}$.

Krashen, S. D. (2002). Second language acquisition and second language learning. California: Pergamon Press Inc. Retrieved from http://www.sdkrashen.com/content/books/sl_acquisition_and_learning.p df

Lizzio, A., Wilson, K., \& Simons, R. (2002). University students' perceptions of the learning environment and academic outcomes: Implications for theory and practice. Studies in Higher Education, 27(1), 27-52. https://doi.org/10.1080/03075070120099359

Lucas, R. I., Pulido, D., Miraflores, E., Ignacio, A., Tacay, M., \& Lao, J. (2010). A study on the intrinsic motivation factors in second language learning among selected freshman students. Philippine ESL Journal, 4(1), 3-23.

Maharsi, I. (2016). The importance of input and interaction in second language acquisition. Journal of English and Education, 5(1), 45-53. https://doi.org/10.20885 亿ee.vol5.iss1.art4

Masgoret, A., \& Gardner, R. C. (2003). Attitudes, motivation, and second language learning: A meta-analysis of studies conducted by Gardner and associates. Language Learning: A Journal of Research in Language Studies, 53(1), 167-210. https://doi.org/10.1111/1467-9922.00212

Mulalić, A., \& Obralic, N. (2016). The relationship between motivation components and preferred learning components among students at the international university of Sarajevo. Epiphany, 9(1), 75-84. https://doi.org/10.21533/epiphany.v9i1.212

Nguyen, V. L., \& Franken, M. (2010). Conceptions of language input in second 
language acquisition: A case of Vietnamese EFL teachers. Language Education in Asia, 62-76. https://doi.org/10.5746/LEiA/10/N1/A06/NguyenFranken

O'Grady, W., Kwak, H.-Y., Lee, O.-S., \& Lee, M. (2011). An emergentist perspective on heritage language acquisition. Studies in Second Language Acquisition, 33(2), 223-245. https://doi.org/10.1017 \$0272263110000744

Opdenakker, M.-C., \& Van Damme, J. (2006). Teacher characteristics and teaching styles as effectiveness enhancing factors of classroom practice. Teaching and Teacher Education, 22(1), 1-21. https://doi.org/10.1016/1.tate.2005.07.008

Punthumasen, P. (2007). International program for teacher education: An approach to tackling problems of English education in Thailand. In The 11th UNESCO-APEID International Conference Reinventing Higher Education: Toward Participatory and Sustainable Development (pp. 1-14). Bangkok, Thailand. Retrieved from http:/backoffice.onec.go.th/uploaded Category/EngBook/ProblemEngEd 13dec07-03-03-2011.pdf

Rajab, A., Far, H. R., \& Etemadzadeh, A. (2012). The relationship between L2 motivational self-system and L2 learning among TESL students in Iran. Procedia - Social and Behavioral Sciences, 66, 419-424. https://doi.org/10.1016/.sbspro.2012.11.285

Samad, A. A., Etemadzadeh, A., \& Far, H. R. (2012). Motivation and language proficiency: Instrumental and integrative aspects. Procedia - Social and Behavioral Sciences, $66,432-440$. https://doi.org/10.1016/.sbspro.2012.11.287

Spratt, M., Humphreys, G., \& Chan, V. (2002). Autonomy and motivation: Which comes first? Language Teaching Research, 6(3), 245-266. https://doi.org/10.1191/13621688021r106oa

Suciati, S. (2016). Cooperative controversy technique to improve students' motivation in English debate. Journal on English as a Foreign Language, 6(1), 43-58. https://doi.org/10.23971 jefl.v6i1.428

Kiatkheeree, P. (2018). Learning environment for second language acquisition: through the eyes of English teachers in Thailand. International Journal of Information and Education Technology, 8(5), 391-395. https://doi.org/10.18178/jiiet.2018.8.5.1069

Vidaček-Hainš, V., Prats, H., \& Appatova, V. (2010). Personal efficacy and factors of effective learning environment in higher education: Croatian and American students. Journal of Information and Organizational Sciences, 34(1), 153-158.

Journal on English as a Foreign Language, 10(1), 45-67

Copyright @ 2020 by JEFL, p-ISSN 2088-1657; e-ISSN 2502-6615 
Wang, X. (2010). Features of Input of Second Language Acquisition. Journal of Language Teaching and Research, 1(3), 282-284. https://doi.org/10.4304/1tr.1.3.282-284

Yin, R.K. (2015). Qualitative research from start to finish. New York: Guilford publications.

\section{Authors' Brief CV}

Arif Nugroho is an English lecturer at the English department of State Islamic Institute of Surakarta. His area of research interest includes second language acquisition and teaching English as a foreign language.

M. Rizal Akbar Zamzami is an English lecturer in the English Education of Raden Rahmat Islamic University, Indonesia. He concerns on English language teaching and linguistics studies.

Nur Farah Ukhrowiyah focuses her research interest in the area of English for specific purposes. She is teaching as an English instructor at Language Center of State Islamic University Maulana Malik Ibrahim of Malang, Indonesia. 